\title{
Teaching the United Nations, gender and critical pedagogy
}

Article

Accepted Version

Holmes, G. (2018) Teaching the United Nations, gender and critical pedagogy. Peace Review, 30 (3). pp. 285-294. ISSN 1040-2659 doi:

https://doi.org/10.1080/10402659.2018.1495805 Available at https://centaur.reading.ac.uk/77978/

It is advisable to refer to the publisher's version if you intend to cite from the work. See Guidance on citing.

To link to this article DOI: http://dx.doi.org/10.1080/10402659.2018.1495805

Publisher: Taylor \& Francis

All outputs in CentAUR are protected by Intellectual Property Rights law, including copyright law. Copyright and IPR is retained by the creators or other copyright holders. Terms and conditions for use of this material are defined in the End User Agreement.

\section{www.reading.ac.uk/centaur}

\section{CentAUR}

Central Archive at the University of Reading

Reading's research outputs online 


\section{Georgina Holmes, University of Reading}

g.holmes@ reading.ac.uk

Georgina Holmes is a Leverhulme Early Career Fellow in the Department of Politics and International Relations at the University of Reading. Her research areas include gender, peacekeeping and security sector reform, and mediatized conflicts in the Great Lakes region of Africa.

*This essay was first presented as a paper at the 'Gender and the Political Academy' conference, University of Cambridge, 2 May 2017.

\section{Teaching the United Nations, gender and critical pedagogy}

\section{Introduction}

Chair of the Committee on Teaching about the United Nations, Anne-Marie Carlson, once argued in UN Chronicle that 'unless students come to know and appreciate the mandate and role of the United Nations in helping their world become safer and more humane, far too many of mankind's failures will simply be repeated.' It is now fairly common practice in British universities for Politics and International Relations departments to offer undergraduate modules that examine the UN's efforts to respond to international security challenges. Investigating complex, multi-level relations of power which structure and operate through the international security institution, such modules aim to teach students about inequalities and social justice. Yet do the critical pedagogic approaches adopted by teachers fully succeed in deconstructing the UN's institutionalised power relations? Applying an intersectional feminist lens to the analysis of curriculum design, I examine how two undergraduate modules taught at British universities between 2013 and 2016 are structured according to a repressive 'neo-liberal gender logic', and consider the implications this has for how gendered war and peace are conceptualised; and how male and female students are socialised as future employees of institutions. I then reflect on the pedagogic practices I have adopted in partnership with students to challenge this repressive logic. 
Feminist scholars have long argued that feminist theory and pedagogy has been pushed to the margins of international relations degree courses. In the early 1990s, Christine Sylvester and others levied criticism that feminist theoretical paradigms were absent in undergraduate teaching because they did not fit, as Christina Rowley and Laura Shepherd have described, 'the dominant rationalist orthodoxy' of the discipline. This rationalist orthodoxy, drawn from Realist and Liberalist paradigms which produce abstract, systemic level analyses, determined how international security institutions were conceptualised through the pedagogic encounter. With the opening up of the discipline and the growing prominence of Critical theory, the old rationalist orthodoxy was required to make way for an expanding and diverse range of paradigms that include less- and non-mainstream theories. Politics and IR departments in British universities have veered towards using 'plural pedagogy' and adopting a multi-paradigm approach to the study of international relations, as John Craig observes.

In spite of continued resistance, the Critical turn in IR and the persistence of feminist scholars has meant that feminist IR theory is now part of the mainstream curricula of most British BA International Relations degree courses. Aside from specialist 'gender modules', the most pronounced discursive space wherein feminist paradigms are incorporated are core IR theory modules which all students are expected to take. Usually taught in year one or year two of the three year degree course, each week of these modules broaches a different theory and observes the evolution of IR theorising - moving from teaching the old rationalist orthodoxy in the first semester to teaching post-positivist theories in the second semester, which is often dedicated entirely to the Critical School.

For Rowley and Shepherd, 'the week on gender', much like the 'chapter on gender' in IR theory textbooks demonstrates little progress towards transforming male-centric engagements with international relations, beyond adopting the 'add women and stir' approach to explaining women's experiences and international security. Proponents of pluralist pedagogy and critical pedagogy may dispute this claim, arguing that these teaching praxes actually prevent the ghettoization of non-mainstream theories and methodologies. The rationale here is that iterative learning combined with critical pedagogy, with its focus on exposing inequalities, challenge dominant and disciplining knowledge claims; facilitate the transformation of existing power relations in society and contribute to institutionalising social justice. Isreali Philosopher Ilan Gur-Ze'ev once wrote that critical pedagogy should be a 
'counter-education' to 'hegemonic-education' and a mechanism through which to resist 'violent practices of normalization, control and reproduction practices in a system that uses human beings as agents and victims'. Key to this, according to the liberatory pedagogy of Paulo Freire, is dialogue between students and teachers, wherein the teaching and learning environment enables

'equal, open and critical intersubjectivity between students and their world.... and in the space in which they are located, as an alternative to power relations within the school and the apparatuses and hierarchies that constitute them.'

With this in mind, it is important to assess how feminist paradigms and gender issues are integrated into individual modules in the context of the overarching structure and learning objectives of the undergraduate degree course, since students will bring to the classroom knowledge of a plurality of theoretical paradigms, as well as personal perspectives.

In UN Chronicle, Carlson advocated for critical pedagogy as the most appropriate approach when teaching about the UN, contending that 'education efforts should not just highlight [the UN's] successes but also acknowledge the limitations and weaknesses that affect [the security institution's] performance'. Six imperatives should be factored into the curriculum design of educational courses. Top of her list was the significance of acknowledging the UN's 'major role in decolonisation and the emergence of some 80 new sovereign states'; 'the huge disparity between the haves and have-nots' and the work of the UN's specialised agencies such as the World Food Programme (WPF) and United Nations Development Programme (UNDP). She also expected students to comprehend the machinations of the institution's principal organs including the Security Council, the Secretariat, the General Assembly and the Economic and Social Council. Without this knowledge - and without developing critical perspectives - students (Carlson's 'younger generation') would be less likely to use 'their creativity and resourcefulness' to solve the global issues the UN seeks to address. While not necessarily destined to work in governments or the UN, this generation would likely become employers and leaders of 'business, service industries, technologies, agriculture and other essential vocations'. Students should develop vested political interests in the UN's external program of work, but should accept the UN's institutional ways of working. 
The curriculum design of the two long-standing modules, taught in British universities between 2013 and 2016 and selected as case studies for this essay, succeed in delivering on Carlson's six imperatives. Both are optional modules available to Politics and IR students, as well as to students studying Law, Economics and History. Case Study A is offered to second year students while Case Study B is offered to finalists, suggesting that students should have a fairly comprehensive understanding of IR theory. The aims of both modules are to examine the effectiveness of the UN's institutional responses to conflict and crises, taking into account exogenous and endogenous factors that determine the international security institution's schizophrenic behaviour. The curriculum design of both therefore require that teachers adopt a pluralist and critical pedagogy so that students can evaluate competing theoretical accounts of the UN's role in maintaining peace and security.

The structure of each module are also remarkably similar to one another and align well with Carlson's objectives. The modules begin with a historical metanarrative of the origin and evolution of the UN and reform of institutional bodies, notably the Security Council and the General Assembly, in relation to decolonisation, the rising influence of states from the global south and regional powers. The second part of the two modules focus on how the UN's institutional agenda has deepened and broadened in response to the changing security environment and the shift towards conceptualising security as 'human security' (within the third world), and this is the entire focus of semester two in Case Study B. In Case Study A, the curriculum is condensed to just one and a half semesters to free up space for a 'mini module' on non-governmental organisations convened by a different lecturer. This leaves little space to debate and theorise the depth of power relations within the UN system. Due to the larger number of students taking Case Study A (on average 60-70), departmental policy dictates that the three seminar tutors follow the same lesson plans to ensure consistency in learning experience. The structure of each week is pre-determined and outlined in the module handbook, thereby restricting opportunities to introduce less mainstream pedagogic approaches. Case Study B is taught in one class, allowing the course convenor greater flexibility.

Within the first three weeks, both modules incorporate one session on the theoretical paradigms deemed most relevant for analysing institutions. These are Realism, Liberalism, New Institutionalism and Constructivism and they are expected to be applied throughout the course during lectures, simulations, workshop exercises and in classroom dialogues. The four 
dominant theoretical paradigms are incorporated to cover the spectrum of macro- and microlevel analysis of institutions, and organisational and political change (or stasis) within them. The centrality of agency-structure debates in New Institutionalism and Constructivism is particularly valuable when analysing change brought on by decolonisation and global inequalities. Yet, with no engagement with post-colonial IR theories, white privilege is reproduced in the pedagogic encounter.

Since critical pedagogy does not rule out the use of alternative theoretical paradigms, if a student wishes to study the UN using a different paradigm - such as a particular strand of feminism - they may do so. After all, students are taught the 'module on gender' prior to taking these two modules and are therefore arguably equipped, at the very least, with the basic theoretical tools to apply a gendered perspective. In this sense, there is an implicit assumption that a feminist theoretical approach can be used, that students have choice, and that students should feel empowered to adopt whatever theoretical paradigm they wish - both in classroom dialogues and in assignments. That saying, in practice, adopting a theoretical paradigm that is not regularly applied in a module can be quite a high risk choice, and one that only the most engaged or politically motivated students in the class are likely to take. The majority of students feel more comfortable using the module's curriculum in assignments.

Gender issues are integrated into the two modules in very controlled ways. Mapping the presence and absence of gendered bodies helps to illustrate this. During the first semester, the only visible person within the UN system itself is the (male) Secretary General, described as a decision-maker, leader, bureaucrat and norm entrepreneur. All other people that work within and interact with the UN system are invisible, despite emphasis that institutions can be conceptualised as social networks. There is no theorising about how the institution itself is gendered, nor how intersectional forms of discrimination that cut across race, class, age, gender, sexuality, ethnic and dis/ability play out in institutional contexts.

In both modules, gendered bodies come into view in the second semester, when the modules focus on the programmes of work delivered by the UN's specialised agencies, such in the topics on the UN's protection agenda (for example, peacekeeping) and the institution's focus on facilitating human security (through achieving the targets of the Millennium Development Goals, now Sustainable Development Goals). At best, the well-rehearsed 
(colonialist) liberal feminist narrative about passive and helpless black and brown women in need of being saved from black and brown toxic masculinities is mobilised. This focus, which incorporates dialogue on the implementation of UNSC Resolution 1325 (Women, Peace and Security), appears to open up space for students to adopt a feminist standpoint - for instance, by utilizing feminist reconceptualisations of security along a 'continuum of violence' - but this paradoxically reinforces the positioning of gender issues as only relevant to the UN's external programme of work. Concurrent with the controlled presence of gender issues, there is a silencing of feminist paradigms such as third wave feminisms which set out to disrupt neoliberal governance feminism located in UN policy discourse, or feminist queer theory which disrupts heternormativity in international relations.

These constraints in the curriculum design determine how the international security institution is conceptualised during the pedagogic encounter. We see the UN 'doing gender', but the UN is an unproblematically genderless (not even gender neutral) institution. Women of the global south are protected individuals, but are a-political and disempowered - neither engaged as political actors in localised conflicts, as I have discussed elsewhere, nor visible as (educated/elite) women advisors, consultants and employees working within UN bureaucracy. Patriarchal orderings of gender, taking account of their varied cultures of origin, and the gendered divisions of labour that structure the neo-liberal economic system and the UN are shunned, while a whole tranche of institutional power relations are bypassed. A false reality is sustained in the configuration of the UN as two kinds of institution, to adapt Inis L. Claude's model. The first institution is a depersonalised collectivity formed by its member states and governed by high politics. This is an accepted zone of conflict and a space constructed out of violent and frictional encounters - as noted in the teaching sessions on intersectional class/race power struggles brought about by decolonisation and internal pressures to reform the Security Council. The second institution, driven by the will of the secretariat, is expected to uphold the foundational (liberal) ideals on which the institution was built - notably social justice. It is imaged as a 'zone of peace', a virtuous institution working to mitigate gendered zones of conflict 'elsewhere' in the world. Despite the application of critical pedagogy, the curriculum design of both modules sustains white privilege and reproduces a repressive internal logic that reinforces the UN's neoliberal gender order.

The institutional neo-liberal gender order can be observed in the decision to create a separate specialised agency - UN Women - to support delivery of the UN's external 
programme of work, while giving the agency limited authority to facilitate system-wide gender sensitive reform within the UN. It came into public view in October 2016 when the UN selected Wonder Woman as the much-needed role model to promote the UN's women's empowerment campaign. The UN's decision to select a white, American woman wearing an overly-sexualised super-heroine costume generated widespread criticism for sending out all the wrong messages about what kinds of female bodies can be empowered - and what empowerment looked like once embodied. Some 40,000 people signed a petition, allegedly drawn up by women on the UN's payroll, and the campaign was dropped two months later.

This leads to the essay's final question. How do undergraduate modules on the UN socialise male and female students as future employees of institutions? Deconstructing the gendered logics of undergraduate modules enables us to examine what kind of consciousness students are expected to develop through the pedagogic encounter. The repressive logics of the two modules, which promote and legitimize the UN's neo-liberal gender order, socialise male and female students to accept the current state of patriarchy of neo-liberal institutions and existing gendered divisions of labour within them. They function as a disciplining tool. Those students who choose to adopt a feminist perspective are encouraged to develop a conservative, neo-liberal consciousness and the skills to 'do gender work', rather than a more radical consciousness required to transform social reality. This belies Carlson's hope for a creative, resourceful future generation to solve existing global issues. For those male and female students who choose not to adopt a feminist perspective, the modules teach students, in the words of Sara Ahmed, 'to learn not to notice' the normalisation of violence in institutions. As future employees, students develop the ability to screen out bodies and performances that threaten institutions. They learn to perform as required of institutions asking critically engaged questions, but not asking awkward questions that might undermine the authority of the institution and jeopardise their positions as employees.

Feminist scholars of critical pedagogy who draw on Gur-Ze'ev and Friere, such as Kathleen Weiler, contend that intersectional feminist teaching 'contains the possibility of transformative work' in its ability to raise the consciousness of students; disrupt the reproduction of sexual divisions of labour within the classroom and in curriculums, and promote democratic relationships and alternative value systems. Pedagogic encounters that address intersectional forms of discrimination, do not simply bring identity politics into the study of international institutions. Refusing to privilege any social category, they disrupt the 
repressive knowledge claims that conceal the UN's internal violent practices of normalisation, perpetrated through the informal and formal rules of the institution, and through the behaviours and performances of UN staff. As Sara Ahmed observes, 'the personal is structural'. To study how international power relations are reproduced through the UN's bureaucracy and through the experiences of individual staff, make the frictional, sometimes violent encounters on which the $\mathrm{UN}$ is built and survives palpable. It shatters the ideational image of the institution's bureaucracy as a zone of peace, pushes for system-wide transformation and compels a rethink how the UN system should function. Such pedagogic encounters contradict the intentions of Carlson, who believed educational courses provided public relations opportunities to secure the UN's legitimacy.

I now reflect on the feminist pedagogic practices I have used when teaching Case Study B. In my experience of working in Politics and IR departments that are resistant to feminism, there is often an unspoken expectation that feminist scholars should embrace patriarchal pedagogy in their teaching of mainstream IR modules, and reserve feminist praxis for specialised gender modules or their own research. There is a fine balance between ensuring that I, a white British feminist teacher, am not repressed and silenced, nor unwittingly reproduce white privilege during the pedagogic encounter, and preventing the disengagement of students who do not choose to adopt a feminist standpoint. Yet, I have found that by bringing students on board as partners in creating the pedagogic encounter, intersectional feminist interventions into the existing curricula can help to disrupt older patterns of teaching and empower students from diverse backgrounds.

I use Carlson's article as a teaching aid to demonstrate how BA curriculums have an internal logic capable of reproducing repressive hierarchies of power. I engage students by encouraging them to critically evaluate how knowledge about the UN is (re)produced in the classroom environment. I explain that unless students themselves, and I the teacher, bring our political and theoretical perspectives drawn from personal experiences and histories into our discussions of the UN, we will be at risk of reproducing the neoliberal logic the UN seeks to promote. I remind students that a plethora of theoretical paradigms, including feminism, postcolonialism and Marxism provide important insights into how institutions function. As an exercise to support this, each week two students must source a relevant new/current affairs article that incites a reaction in them - either positively or negatively - in order that they may share their political and theoretical opinions with the group. 
I introduce Feminist Institutionalism, which accounts for multi-level power relations within institutions, as a fifth theoretical paradigm early on in the module. This intervention provides students interested in feminist perspectives with the opportunity to further build on the foundational 'week on gender' and specialist gender courses. Yet since Feminist Institutionalism both counters and responds to New Institutionalism, as Fiona Mackay et.al. suggest, the paradigm generates dialogue across the different theoretical approaches and enrichens the student's understanding of new institutionalism - the only theory of which students do not have prior knowledge. I also draw on the wealth of academic literature produced by feminist scholars that broach structure-agency debates, formal and informal institutions, and continuity and change through a gendered lens This includes research on transnational networks; Martha Finnemore, Kathryn Sikkink, Jackie True and Mona Krook's theorising of norm dynamics; Hillary Charlesworth's analysis of gender mainstreaming across the UN's specialised bodies and Soumita Basu's compelling study of the appropriation of the Women, Peace and Security agenda in the foreign policy of member states. This intervention has made the module reading list more gender and race equitable.

Contemporary case studies help students observe how violence and coercion operate through the UN's bureaucracy. The appointment of the Secretary General in 2016, and the \#SheMatters campaign led by campaign group Equality Now, which raised the profile of women candidates is one such example. Exploring how the campaign evolved via transnational networks and the international media; how female and male candidates performed during live debates and examining the final voting outcome in relation to geopolitics and decision-making within the Security Council succeeds in deconstructing the artificial divide between the two UNs. A second case study on SG Antonio Guterres's support for the \#HeforShe campaign explores political implications of silencing and excluding individuals, and students observe how the lesbian, gay, bisexual, and transgender (LGBT) community has criticised the UN's failure to recognise gender fluidity within the institution. As does a third case study on the refusal of the majority of Human Rights Council members to accept LGBT rights. In the second semester, students draw causal links between institutional violence and the implementation of the UN's external program of work. For example, peacekeeper sexual exploitation and abuse is an institutional failing at all levels of the UN, not simply a failing of militaries from predominantly the global south. 
The intention of these feminist pedagogic interventions is not to 'engender' teaching about the UN per se, but to offer up alternative possibilities that enrichen the study of international security institutions and teach students how as prospective employers and employees they can facilitate social justice.

\section{$\underline{\text { Recommended readings }}$}

Ahmed, Sara, 2017. Living and Feminist Life, Durham/London: Duke University Press.

Carson, Anne-Marie, 2013. 'Is it still necessary to teach about the United Nations?', UN Chronical. https://unchronicle.un.org/article/it-still-necessary-teach-about-united-nations, accessed 15 August 2017.

Claude, Inis, 1996. 'Peace and Security: Prospective Roles for the Two United Nations' in Global Governance 2, pp. 289-298.

Craig, John, 2012. 'What (if Anything) is Different about Teaching and Learning in Politics?', in Teaching Politics and International Relations, edited by Cathy GormleyHeenan and Simon Lightfoot, Basingstoke: Palgrave Macmillan.

Gur-Ze'ev, Ilan, 1998. 'Toward a Nonrepressive Critical Pedagogy', in Education Theory, Fall, 48:4, pp. 463-486.

Holmes, Georgina, 2013. Women and War in Rwanda: Gender, Media and the Representation of Genocide, London: New York: I.B Tauris.

Mackay, Fiona; Kenny, Meryl and Chappell, Louise, 2010. 'New Institutionalism Through a Gender Lens: Towards a Feminist Institutionalism?' in International Political Science Review, 31:5, pp. 573-588.

Rowley, Christina and Shepherd, Laura, 2012. 'Contemporary Politics: Using the ' $F$ ' Word and Teaching Gender in International Relations' in Teaching Politics and International Relations, edited by Cathy Gormley-Heenan and Simon Lightfoot, Basingstoke: Palgrave Macmillan.

Weiler, Kathleen, 2002, The Critical Pedagogy Reader, edited by Antonia Darder, Rodolf D. Torres and Marta P. Baltodano, New York/London: Routledge. 